\title{
Research on Degradation Processes by Soil Erosion in the Plapcea Catchment, Olt County
}

\author{
Mariana BURCEA ${ }^{1}$, Emil GEORGESCU ${ }^{2}$, Marian MUSAT $^{1}$, Daniela CRETU ${ }^{1}$ \\ ${ }^{1}$ University of Agricultural Sciences and Veterinary Medicine, Bucharest, 59 Marasti, District 1, 011464, \\ Bucharest, Romania; \\ ${ }^{2}$ National Agricultural Research and Development Institute Fundulea, Romania; \\ * corresponding author: emilgeorgescu2013@gmail.com
}

Bulletin USAMV series Agriculture 72(1)/2015

Print ISSN 1843-5246; Electronic ISSN 1843-5386

DOI 10.15835/buasvmcn-agr: 11166

\begin{abstract}
The soil in his complexity can be understood in terms of the known and the particular natural environment in which it developed and evolved. He is a real natural history, which appears as a summary plan knowledge organically bound constants and subsequently pedogenetical development environment other items.This paper presents a study of soils from Plapcea Basin area, covering 25,000 ha, located in the south of the country, in its Cotmeana Piedmont, Piedmont subdivision. The soil cover of Piedmont Cotmeana first observations belong to Murgoci and collaborators (1910), these two areas of soils mentioning: the reddish brown soil, much expanded to actual representation and the podzols. Physical and geographical conditions of the area, parental materials, sediment soil formation and composition of various size clay deposits, of which only clay $(<0.002 \mathrm{~mm})$ over $55 \%$, lead to accelerated erosion of these soils. Based on the study of the natural and the coating of soil erosion intensity was translated into a map of soil erosion occurs as the limiting factor in terms of slope relief, which aside hundreds of acres of land.
\end{abstract}

Keywords: erosion, hydrographic basin, luvisol, pedogenesis, soil classes.

\section{INTRODUCTION}

The soil can not understand and can not perceive the qualities of, if not known, and the peculiarities of the natural environment in which it developed. He is a real natural history, which appears as a summary plan knowledge organically bound constants and subsequently pedogenetical development environment other items.

The morphology of the region is studied through the landscape, analyzed as the result of a long evolution (Ghinea et al., 1982). Assembly factors specific pedogenetical Plapcea basin led to the formation of ground cover rather complex are present a number of clearly differentiated types and subtypes, most of them belonging to the class Luvisols.
Regarding Cotmeana Piedmont area where the hydrographic basin is located, may be mentioned some geological surveys, soil studies and even geobotanic ones. (Popovăț et al.,1959).

The geological studies are divided into two categories: some summary, which includes only references to the geological structure and paleogeographic evolution of the region and belong to a large number of specialists from Ștefănescu (1866), Drăghiceanu (1895), Lițeanu (1971), Oncescu (1957), Popovat (1961) and Dragu (1962), the enhancement of water supplies and building materials in the region that have dealt Oncescu et al. (1948), Haret (1963) and a team led by Liteanu (1971). 


\section{MATERIALS AND METHODS}

The investigated area is more than $25.000 \mathrm{ha}$, located in the south of the country, throughout the Cotmeana Piemont subdivision of Getic Piemont.

For the study undertaken were performed data analysis and interpretation in the research have been undertaken in the south-eastern county of Olt. Soil type analysed is Albic Luvisols, and it occupies the largest area in the study area.

Documentation, it is a key element, which are updated pedogenetic processes and phenomena that pose problems for agriculture, given the natural environment.

The methods used in determination of soil classes, ware done according to Soil Survey Methodology (ICPA, 1987) and Romanian System of Soil Taxonomy (SRTS, 2003).

By using the map on scale 1:200,000, were identified 14 soil taxonomic units, plus variants affected by varying degrees of erosion and soil associations. Statistical analysis highlighted Luvisols, with nearly three quarters of the area studied $(77 \%)$. The analysis of topographic maps and longitudinal profiles, it appears that the investigated basin Plapcea corresponding inclined from north to south.

\section{RESULTS AND DISCUSSIONS}

Under the influence of simultaneous and associated pedogenetic factors, Plapcea Basin, formed a wide range of soils, wich according with Romanian System of Soil Taxonomy (2003) belong to classes: Entisols, Cernisols, Cambisols, Luvisols and Hydrisols (Tab. 1).

\section{Entisols}

These soils occupy an area of $1,550.5$ ha (5.81\%) and are present in the territory by type: regosols subtype eutric and fluvisols subtype eutric. Regosols that are presented on 275.5 ha $(1.33 \%)$ are local widespread on slopes of Plapcea's (Small and High) and Negrișoara's Rivers with their tributaries.

\section{Cernisols}

Cernisols are represented only in the territory of Calcaric Phaeozems, and are presented on less than $3 \%$ of the basin Plapcea area. These soils have calcium carbonate present in the first 50 cm. Researchers studied Getic Piemont (Popovăt, 1952; Parichi, 1970) reported in this region, soils known as „Piscupia complex” consisting of leptosols. Originally relief interfluves that developed "complex Piscupia soils" was smooth and composed of clay sediments rich in $\mathrm{CaCO}_{3}$.

Tab. 1. Soils class, type and subtype in the Plapcea basin (ha, \%).

\begin{tabular}{|c|c|c|c|c|c|}
\hline \multicolumn{6}{|c|}{ PROTISOLS - 1,550.5 ha (5.81\%) } \\
\hline Type & ha & $\%$ & Subtype & ha & $\%$ \\
\hline Regosols & 275.5 & 1.04 & Eutric & 275.5 & 1.04 \\
\hline Fuvisols & $1,275.0$ & 4.77 & $\begin{array}{l}\text { Entic } \\
\text { Eutric }\end{array}$ & $\begin{array}{c}175.0 \\
1,100.0\end{array}$ & $\begin{array}{l}0.65 \\
4.12\end{array}$ \\
\hline \multicolumn{6}{|c|}{ CERNISOLS - 687.3 ha (2.58\%) } \\
\hline Phaeozem & 687.3 & 2.58 & Calcaric & 687.3 & 2.58 \\
\hline \multicolumn{6}{|c|}{ CAMBISOL $-1,862.5$ ha $(6.98 \%)$} \\
\hline Eutric Cambisols & $1,862.5$ & 6.98 & Fluvic & $1,862.5$ & 6.98 \\
\hline \multicolumn{6}{|c|}{ LUVISOLS- $20,504.4$ ha $(76.82 \%)$} \\
\hline Haplic Luvisols & $12,397.2$ & 46,44 & $\begin{array}{c}\text { Typic } \\
\text { Molic } \\
\text { Stagnic Molic } \\
\text { Stagnic } \\
\text { Erodated } \\
\end{array}$ & $\begin{array}{c}235.2 \\
412.5 \\
1,370.5 \\
4,672.0 \\
2,256.0 \\
\end{array}$ & $\begin{array}{l}0.88 \\
1.54 \\
5.13 \\
17.5 \\
8.45 \\
\end{array}$ \\
\hline Luvisols & $8,107.2$ & 30.36 & $\begin{array}{c}\text { Stagnic } \\
\text { Stagnic - melanic } \\
\text { Albic stagnic } \\
\text { Albic stagnic - melanic }\end{array}$ & $\begin{array}{c}414.5 \\
3,575.0 \\
550.0 \\
3,567.7\end{array}$ & $\begin{array}{c}1.50 \\
13.40 \\
2.06 \\
13.40\end{array}$ \\
\hline \multicolumn{6}{|c|}{ HYDRISOLS - 2,062.5 ha (7.83\%) } \\
\hline Stagnosols & $2,062.5$ & 7.83 & Tipic Stagnosols & $2,062.5$ & 7.83 \\
\hline Total & $26,667.2$ & 100.0 & & $26,667.2$ & 100.0 \\
\hline
\end{tabular}


Once exposed sub-aerial factors, these sediments came into the soil formation where washing with carbonates, leading to the formation of Stagnic Phaeozems.

Calcaric Phaeozemsm, occur more frequently in the southern half of the territory in the floodplain terraces of the two valleys' Plapcea as Negrișoara. They were formed under a plan relief relatively drained, on silty loam-loam sediments.

\section{Cambisols}

In Plapcea Basin they are present Fluvi-eutric Cambisols, which occupies an area of over 1,800 ha.

\section{Luvisols}

Luvisols are the most widespread in the area (76.90\%) and are represented by types Haplic Luvisols and Luvosols. Haplic Luvisols (typical clay soils SRCS-1980) occupies about 412.5 ha (1.54\%) of territory, followed by Haplic Luvisols mollic and stagnic.

They meet at the southern extremity of the territory, on the inter valley NegrissoaraPlapcea Mică and upper terrace of Plapcea Mare, imperfectly drained, formed on fine clayish sediments.

\section{Hydrisols}

In Plapcea Basin, hydrisols are represented only by tipic Stagnosols. These soils are found only in the southern half of the territory, Negrisoara Valley Basin, covering over 2,000 ha (8\%). Were formed under conditions of very low relief with natural drainage, consisting of fine sediments, such as clays deluvial-proluvial.

\section{erosion \\ Processes of soil degradation through}

Slopes occupy Plapcea Basin on around 24\%. In the period in which they were covered with natural vegetation (forests and pastures), soil erosion was insignificant. Simultaneously, however, the removal of vegetation, the award for the most poor pasture land parceling and orientation of lots on line of greatest slope without safeguards began to emerge and increase soil erosion.

The main valleys and their tributaries were flowing north-south direction and presents slopes east or west exposure, hence the most advanced degree of erosion on the western slopes. Regardless of the exhibition, however, stronger inclined slopes (15-30\%) including in forest erosion occurs with increased intensity.

An important role in the amplification of soil erosion had and lithological diversity of parent material (sand, gravel, clay marl) and their instability. Another role was played by human activities (soil tillage, fertilizer application etc.) where the soil was subjected to morphological changes, physical, chemical and biological (M. Musat, Alexandra Radu, 2007).

One of the dominant factors of soil erosion is the particle size distribution. As apparent from Table 2, in the particle size distribution of deposits fine clay, silt and clay have on average $76 \%$, of which only clay $(<0.002 \mathrm{~mm})$ greater than $55 \%$, resulting in a strong process of erosion. Layer of soil from the area studied occurs unevenly developed since its dynamic action the rainfall gradually removed varying amounts, the superior soils on sloping land, reaching up to the total removal of the topsoil and removing the surface horizons and sometimes infertile parent rock.

Surface erosion (Fig. 1) is present over large areas on the basin slopes. Deep erosion, unlike of surface that, is required by the presence of permanent forms, basins and ravines that forward regression slope causing a fragmented whole. The first signs of erosion in the area, have appeared with increasing the density of deforestation and fragmentation of relief that meant interrupting

Tab. 2. Particle size distribution in Plapcea Mare Basin

\begin{tabular}{lccccccc}
\hline \multirow{2}{*}{ Location } & \multirow{2}{*}{$\begin{array}{c}\text { Depth } \\
(\mathrm{cm})\end{array}$} & Clay & Silt & Fin sand & $\begin{array}{c}\text { Gross } \\
\text { sand }\end{array}$ & $\begin{array}{c}\text { Physical } \\
\text { clay }\end{array}$ & Fine clay \\
\cline { 3 - 8 } & & $<0.002$ & $0.002-0.02$ & $0.02-0.2$ & $0.2-2$ & 0.01 & 0.001 \\
\hline \multirow{2}{*}{ Scornicești } & $163-183$ & 54.1 & 27.8 & 17.0 & 1.2 & 69.2 & 51.2 \\
\hline \multirow{2}{*}{ Alunișu } & $230-250$ & 55.1 & 25.9 & 18.9 & 1.1 & 68.2 & 50.8 \\
\hline & $160-180$ & 55.1 & 25.0 & 18.5 & 1.4 & 68.6 & 52.2 \\
\hline
\end{tabular}




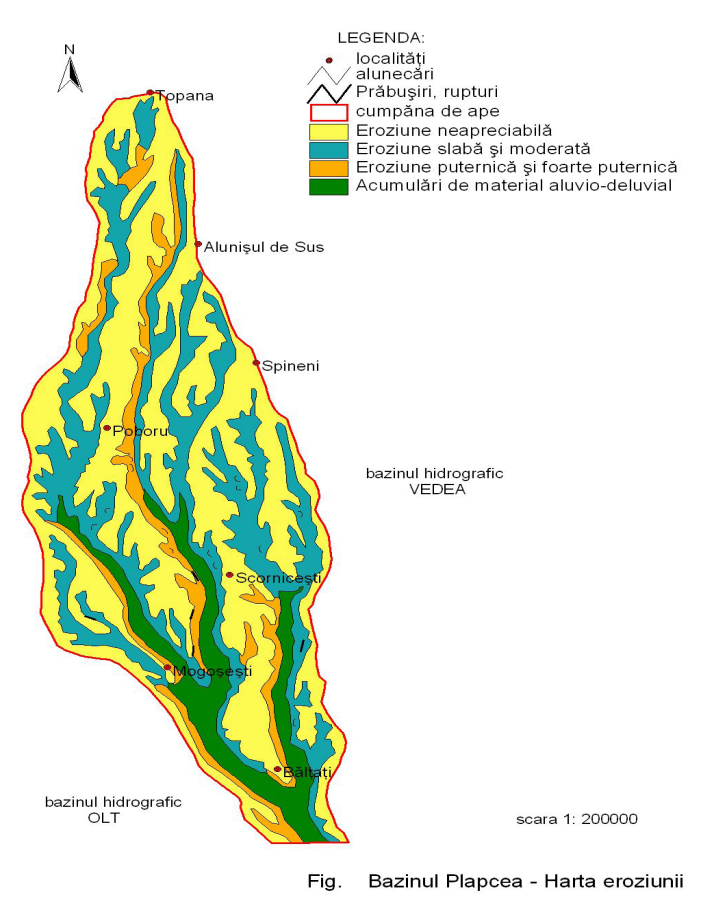

Fig. 1. Soil erosion map - Plapcea Basin

the continuity of the ground units. Subsequent erosion has intensified due to other causes, some socio-economic, natural others.

\section{Causes of erosion are:}

a. Soil tillage of slopes, on the hill to valley perpendicular to the contour, due to the farm property is broken into small parcels that area, which accelerates erosion;

b. Culture system is dominated by maize, plant wich does not provide protection against soil degradation processes;

c. The torrential regime of rainfall falling in late spring and early summer, affecting large areas sloping topography, where water removed tons of soil material that rolls up in riverbeds. At the same time, strongly inclined slopes produced massive landslides and collapses occur in the upper third of the land. It was found that the most seriously affected by erosion, are exposed to the south and west slopes, which could be related to vegetation presenting less abundant.

Based on the study of the natural and the soil cover was drawn map soils affected by different degrees of erosion.

The complex character of the landscape, and especially the slopes, the degree of their kneading and soil erosion, has allowed us to distinguish Plapcea basin's erosion following forms:
- Soils with insignificant erosion;

- Soils with small to moderately erosion;

- Soils with high and very high erosion;

- Accumulation of alluvial material-deluvial;

- Soils affected by landslides;

- Soils affected by the crash.

Soil quality is increasingly affected, to a lesser or greater than one or more restrictions. Their harmful influences are reflected in the deterioration of soil characteristics and functions, ie their ability bio.

\section{CONCLUSIONS}

Luvisols are the most widespread in the area (76.90\%) and are represented by types Haplic Luvisols and Luvisols, followed by Hydrisols (7.83\%), Cambisols (6.98\%), Protisols (5.81\%) and Cernisols (2.58\%).

Parental materials represented the predominant silty clay, clay fraction (50-60\%), followed by silt (27-34\%) favored the formation of large areas of Luvisols in the most affected by waterlogging, which put special problems regarding their agricultural use.

Particle size distribution of clay deposits, fine material (silt and clay) has averaged 76\%, which favors a strong process of erosion under the influence of rainfall, which is enhanced by the slope.

Conditions torrential rainfall falling in late spring and early summer, affecting large areas sloping topography, the water removed tons of soil material. In order to avoid soil erosion and soil formation resumption recommended afforestation and from case to case, tillage direction and contours of organic fertilizer and chemical application.

\section{REFERENCES}

1. Dragu I (1962). Cercetări geobotanice în platforma Cotmeana, D. de S., Comit. Geol., XLIII.

2. Ghinea P, Andreiași N, Teodorescu A, Seceleanu I, Tudor A (1982). Considerații asupra învelișului de soluri din comuna Scornicești, Jud. Olt, Lucr. celei de a XI-a Conf. Naț. S.N.R.Ș.S., Brăila.

3. Haret C (1963). Contribuții la rezolvarea problemei apei pentru agricultură în platforma Cotmeana, I.S.C.H., Stud. de hidroameliorații II, București.

4. Liteanu E, Ghenea C, Mihăilă N, Giurgea R (1971). Despre geologia și hidrogeologia Platformei Cotmeana, D. de S. ale Inst. Geol., Seria H.

5. Murgoci GM (1910). Zonele naturale de soluri din România, Anal. Inst. Geol. al României, vol. 4, fasc.1. 
6. Musat M, Alexandra R, (2007). Geologie si geomorfologie, Ed. Printech, Bucuresti;

7. Mușat M, Burcea M, Radu A (2013). Pedoagrotehnică, Ed. Ceres, București.

8. Oncescu N, Dragoş V, Motaş I (1948). Raport preliminar asupra problemei apei potabile în regiunea Cotmeana, jud. Argeş și Olt, Arh. Inst. Geol., București.

9. Popovăț M (1961). Caracterizarea climatică a solurilor din R.S.R. cu ajutorul indicilor climatologici. Cercetări de pedologie, Bucureşti.

10. Parichi M (1970). Prospecțiuni pedologice în Piemontul Cotmeana, Arhiva ICPA.

11. Parichi M (2001). Piemontul Cotmeana - studiu fizicogeografic cu privire specială la soluri, Edit. Fundației România de Mâine, Bucureşti.
12. Popovăț A, Rapaport C, Dragu I (1959). Procese de eroziune în partea de vest a Platformei Cotmeana, Comit. Geol., Stud. Tehn., Seria C, nr. 11.

13. ***(1987). Metodologia elaborării studiilor pedologice, I.C.P.A., vol.3.

14. ${ }^{* * *}(2012)$. Sistemul Roman de Taxonomie a Solurilor (SRTS).Ed. Sitech, Craiova.

15. ***(1980). Sistemul Român de clasificare a solurilor, București.

16. ***Harta solurilor României, scara 1: 200.000, foile Slatina şi Piteşti. 